Volume 8, No.5, September - October 2019

International Journal of Advanced Trends in Computer Science and Engineering

Available Online at http://www.warse.org/IJATCSE/static/pdf/file/ijatcse69852019.pdf

https://doi.org/10.30534/ijatcse/2019/69852019

\title{
Student Behavior and Performance in Unsupervised Online Quizzes: A Case of Computer Organization Course
}

\author{
Norliza Katuk \\ School of Computing, Universiti Utara Malaysia, Malaysia, k.norliza@uum.edu.my
}

\begin{abstract}
The paper describes a study on the relationship between students' online quiz taking behavior and their performance. Unsupervised online quizzes have been used widely by higher learning institutions as an activity in a blended learning model and found to be a valuable formative assessment tool for students to self-assess their learning more flexibly and conveniently than taking the quizzes in the classroom. Past studies also suggested that online quizzes could engage students in learning more effectively and increase students' motivation to learn more than inclassroom quizzes. Although the online quizzes offered positive effects on students' learning, limited studies were conducted to understand students' behaviors in taking unsupervised online quizzes and how they affect their performance. Therefore, this study aims to investigate how students' online quiz taking behavior affects their performance. Four types of ordinary online quiz taking behavior, namely (1) access to printed references, (2) access to digital references, (3) peer discussion, and (4) test preparation practices are included in the study. The students' online quiz taking behavior was obtained using a self-rated post-task questionnaire, while the performance data of the students were taken from their scores in three unsupervised online quizzes for a Computer Organization course, as a compulsory course for students enrolling in an Information Technology bachelor's degree program. The results of the study suggested that students who frequently access to printed references, access to digital references, and have peer discussion during online quiz taking obtained higher marks for the online quizzes compared to the students who never or seldom do so. A similar result also found among students who prepared or did revision before taking the quizzes. Further, students who obtained higher marks in the online quizzes tend to refer to digital references (i.e., softcopy of the lecture notes, and search from the Internet) more frequently than the students who obtained lower marks. The findings of the study suggested that preparation and revision before the quizzes are essential, although there are resources available to refer to while taking the unsupervised online quizzes.
\end{abstract}

Key words: learning, students, online quiz, quiz-taking behavior, learning systems

\section{INTRODUCTION}

Technology-enhanced learning has transformed the traditional teaching and learning activities into a modern learning environment. Many new terms emerge along with technological advancements such as electronic-learning [1], mobile-learning [2], and game-based learning [3]. Nevertheless, electronic-learning (e-learning) has been the common term used to refer to a type of learning mode that depends on the use of the Internet [4]. The e-learning system is also known as a virtual learning environment developed to support and facilitate the teaching and learning process by using a more flexible approach than traditional learning [5]. E-learning can be effectively implemented using a learning management system, a kind of learning software that features educational content in a structured manner and provides a virtual platform for teaching and learning [6]. Higher learning institutions today have widely implemented elearning to encourage independent and lifelong learning, primarily to support distance learning. Teaching and learning activities, including assessments, are conducted in a virtual mode where students participate in the activities through learning management systems.

The learning management systems provide a platform that facilitates instructors to design online assessments, including assignments, quizzes, and tests, without the need for a faceto-face meeting. From the students' perspective, they could submit the assignment and answer the quizzes and tests in an unsupervised mode, which fosters independent learning. Unsupervised online learning has been a topic of interest among researchers, which encouraged many studies. Past studies have proved that online learning could engage students in learning more effectively than attending face-toface lectures [7],[8]. Although online learning affects the students' engagement in learning, the effect of unsupervised online quizzes on students' performance is not thoroughly studied. Students' performance in learning could be influenced by many aspects [9],[10] including background, learning environment, government policies, attitudes, and behaviors. Generally, students' behaviors can be used to predict their performance in learning [10]. In the context of students' behavior, it is still not known whether students' behavioral aspects while answering the unsupervised online quizzes influence their performance. Further, what are 
students' behaviors in answering unsupervised online quizzes that are relevant in predicting their performance in learning? These two questions have been the primary topic of the study presented in this paper. The remaining of this paper is divided into four sections. Section 2 discusses related studies followed by the methodology for conducting the study in Chapter 3. Next, the analysis and results of the study are elaborated in Section 4. The last section provides the conclusion and potential future works.

\section{RELATED STUDIES}

Higher learning institutions currently implement blended learning approaches [11], where e-learning is combined with face-to-face lectures in their academic programs. Blended learning has a percentage of independent learning through the use of various electronic media [12]. It has become popular as an alternative delivery model for university courses [13] and has been found to enhance students' understanding during their learning process [14]. Apart from blended learning, the flipped classroom is a new and popular teaching model, where traditional activities in the classroom become home-based activities and the other way around [15]. Both blended learning and flipped classroom may be conducted through various e-learning activities such as watching videos about a topic in the course syllabus and answering online quizzes. Past studies have shown that materials, readings, and quizzes performed online are better than listening to the professor's lectures through PowerPoint in the classroom [13]. Previous studies also proved that online learning improved student academic performance and enhanced student confidence in the course of software programming [16].

The discussion in this paper focuses on online quizzes as an activity and assessment for a blended learning model. Online quizzes are valuable educational tools, which allow students to self-assess their learning process anytime, anywhere, and anytime, receive instant feedback on their performance [17]. Past studies also proved that online quizzes could engage students in learning more effectively than attending face-toface lectures [7],[8]. Online quizzes have also been found as a good motivating factor for students to participate in blended learning [18]. Kibble [19] conducted a study and found that more than $90 \%$ of the students agreed that online quizzes could help students keep up with studies and their learning. In another study by Paturusi, Chisaki, and Usagawa [20], it is reported the assessment tool enhanced students' performance in learning in which the students performed self-assessment of their learning performance through automatic grading function. Shimizu, Nakazawa, Sato, Wolfhagen, and Könings [21] suggested that blended problem-based learning with online quizzes has been effectively retaining authority and enhancing students' selfefficacy and their learning motivation due to peer discussions.
Pinto-Llorente, Sánchez-Gómez, and García-Peñalvo [8] pointed out the potential of online quizzes for continuous assessment and to self-assess students' progress in learning second languages. The study argued that online quizzes could foster independent learning and facilitate formative assessment to guide students in the process of mastering a second language. On the other hand, Dobson [22] stated that online quizzes could predict students' marks of the summative assessment. The study found that physiology students who completed formative online quizzes scored higher in their summative examinations than students who did not complete the quizzes. They found that the online quizzes motivated the student to prepare earlier for the summative examinations. Online quizzes in a blended learning environment facilitate teachers and instructors in managing the class assessments. In the traditional face-toface learning environment, providing timely feedback for the formative assessments is challenging, especially for large classes; therefore, teachers and instructors opt for online quizzes for instant grading and feedback [23]. Teachers and instructors also used online quizzes to measure students' independent learning behavior while out-of-class on given online learning materials [24].

Students' performance is a standard measure for evaluating the effectiveness of the e-learning environment [25], including online quizzes. Despite the fact that the positive outcomes of the online quizzes to students and teachers, analysis of the literature have also revealed an opposite finding. Steenhuis, Grinder, and De Bruijn [26] found that online quizzes do not significantly improve student learning. This claim could be valid when considering learning as a complex process that linked to personal attitudes, behaviors, learning styles, prior knowledge, and learning speed. In some e-learning studies, control over learning material is a critical component that affects students' motivation, performance, and attitudes towards learning [27]. Control is characterized by the way how the students interacted with online quizzes from their behavioral perspective that could affect the performance in learning. However, limited studies were conducted to understand how student interactions and student engagement may affect the learning outcomes among students [28]. Therefore, there is a need to study students' online quiz taking behavior and how their behavior could relate to their performance in learning. This study investigates how students' online quiz taking behavior affects their performance to fill the gap. Four types of ordinary students' online quiz taking behavior are identified, namely (1) access to printed references, (2) access to digital references, (3) peer discussion, and (4) test preparation practices.

In unsupervised online quizzes, students could find answers for the quizzes from many sources as they have not been invigilated. Students could ask the questions and answers from peers who have taken the quizzes earlier, search the answers from textbooks and lecture notes, or search the 
questions and answers from the Internet. Some past studies have classified this action as a cheating behavior [29]. Watson and Sottile [29] reported that students were more likely to search for answers for the quizzes from other sources during online quizzes rather than preparing and making a revision before taking the quizzes. Kibble [19] investigated the role of unsupervised online quizzes in determining the students' final grades among medical students. The study implemented a few models, including voluntary participation and assigning credits to participation. The results suggested that students scored full marks during the first attempt of the unsupervised online quiz; however, they did not perform well during the final examination when credits were assigned to reward the participation. Nevertheless, Kibble argues that this action was not defined as cheating, as no rules were stated in taking the quizzes.

Many factors influence cheating and academic dishonesty during tests and examinations. For example, younger students tend to cheat more than older age students, and students in face-to-face mode tend to cheat more than online mode [30]. It has been a challenge within academic institutions to maintain academic integrity when it comes to online assessments [31]. It is almost impossible to avoid students from referring to other sources during the quiz taking time, even when the students' web-camera is activated. However, some approaches can be taken to maintain the purpose of online quizzes, for example, limit the duration of answering the quizzes, reshuffling the order of the questions, and use short-answer questions instead of multiple-choice. Further, when academic institutions ready to move to unsupervised online assessments, it means that they are ready to accept the implications of the assessment method in which students are now allowed to access external sources when taking the quizzes. Therefore, the term "cheating" in unsupervised online quizzes might not be relevant anymore as the technology is now changing the traditional assessments to be more open and flexible. It could be a way to reduce the stress and tense in taking quizzes among students, which leads to improved learning performance.

Student behavioral studies in unsupervised online quizzes are important to understand the effects of their behaviors on the overall learning process and performance. There are many aspects of behavioral studies that can be investigated concerning unsupervised online quizzes. For example, Gholami and Zhang [32] analyzed students' activity log in unsupervised online quizzes by specifically looked at the number of participants, the number of trials, and the starting time. The results of the analysis suggested that there is a correlation between the students' performance in the quizzes with their final examination for students who have active learning habits. The use of technology, for example, mobile devices in learning, has also changed students' learning habits [33] in which the students are able to learn in a more flexible way in which they have more options for the locations and greater range of learning tasks can be performed. In the context of unsupervised online quizzes, this study attempts to investigate students' learning habits. It specifically focuses on students' access to printed references, digital references, peer discussion, and test preparation practices.

\section{METHODOLOGY}

\subsection{Method}

An experimental study was conducted to investigate the students' online quiz taking behavior. The independent variable is the students' performance represented by the average marks or scores obtained from the three online quizzes, while the dependent variable is the students' online quiz taking behavior that is characterized by access to printed references, access to digital references, peer discussion, and test preparation practices. Two hypotheses were constructed for the study:

H1 - The students' online quiz taking behavior has a relationship with their performance,

$\mathrm{H} 2$ - Students who scored higher marks have different online quiz taking behavior than the students who scored lower marks.

\subsection{Participants}

This study utilized data of 39 students who took Bachelor of Science in Information Technology offered by a public university in the northern region of Malaysia. All students enrolled in the course during the second semester of the 2018/2019 session were included in the study, which comprised 12 males and 27 females. The students enrolled in an introductory course named Computer Organization as a compulsory course for the programs. The study was conducted as an approach for continuous improvements in teaching and learning implemented by the university. The academic session was carried out in fourteen weeks of teaching and learning starting in the second week of February until the third week of May 2019. The online quizzes contributed $15 \%$ to the overall marks and assessments for the course, where the individual course weights $5 \%$. The course was conducted in a blended learning model where $30 \%$ of the teaching and learning activities were conducted through electronic and online media.

\subsection{Materials}

The primary materials used in the study were the online quizzes and post-task questions. The unsupervised online quizzes were conducted on a customized Moodle, an opensource learning platform utilized by the university. Three different unsupervised online quizzes were given to the students in week 5 , week 9 , and week 14 of the academic session. The topics for the online quizzes were Binary Numbers, Logic Gates, and Central Processing Unit (CPU) for the respective quizzes. The post-task question was given 
to the students to get the data for online quiz taking behavior. It contained ten questions covering seven typed of behavior, as summarized in Table 1. Question A1 to A4 provided the students with the options of the answer. For questions B1 to B6, a five-point Likert scale was used (i.e., one represents never, and five represents always).

Table 1: The post-task questions

\begin{tabular}{|c|c|c|}
\hline Code & Items & $\begin{array}{l}\text { Types of } \\
\text { Behavior }\end{array}$ \\
\hline A1 & $\begin{array}{c}\text { What is your favorite feature of } \\
\text { online tests? }\end{array}$ & \multirow{2}{*}{$\begin{array}{l}\text { Likes and } \\
\text { dislikes }\end{array}$} \\
\hline $\mathrm{A} 2$ & $\begin{array}{l}\text { What feature of online quizzes } \\
\text { that you do not like? }\end{array}$ & \\
\hline A3 & $\begin{array}{l}\text { Where do you usually take } \\
\text { online quizzes? }\end{array}$ & Choice of venue \\
\hline A4 & $\begin{array}{l}\text { What device do you usually use } \\
\text { to take online quizzes? }\end{array}$ & Choice of device \\
\hline B1 & $\begin{array}{l}\text { When taking online quizzes, I } \\
\text { use the textbook as a reference }\end{array}$ & \multirow{2}{*}{$\begin{array}{l}\text { Access to printed } \\
\text { references }\end{array}$} \\
\hline B2 & $\begin{array}{l}\text { When taking online quizzes, I } \\
\text { refer to the printed lecture notes }\end{array}$ & \\
\hline B3 & $\begin{array}{l}\text { When taking online quizzes, I } \\
\text { search the answer from the } \\
\text { Internet }\end{array}$ & \multirow{2}{*}{$\begin{array}{l}\text { Access to digital } \\
\text { references }\end{array}$} \\
\hline B4 & $\begin{array}{l}\text { When taking online quizzes, I } \\
\text { refer to the softcopy of the } \\
\text { lecture notes }\end{array}$ & \\
\hline B5 & $\begin{array}{l}\text { When taking online quizzes, I } \\
\text { discuss with my friends }\end{array}$ & Peer discussion \\
\hline B6 & $\begin{array}{l}\text { I always study earlier before } \\
\text { taking the online quizzes }\end{array}$ & $\begin{array}{l}\text { Test preparation } \\
\text { practices }\end{array}$ \\
\hline
\end{tabular}

\subsection{Procedures}

The students were given a maximum of 30 minutes for each quiz. They could answer the quizzes at any time between 8 am to $8 \mathrm{pm}$ of pre-informed dates. The online quizzes were organized in sequential order, where the students were not allowed to return to the previous questions. Upon completion of the quizzes, the scores of the quizzes were rendered to the students, and the system marked the answers as correct or incorrect. The real answer to the questions was available the next day. The students answered the post-task questions during the last day of the semester using Google Form.

\section{RESULTS AND DISCUSSIONS}

The data of the study were analyzed using IBM SPSS Statistics Version 25. A normality test using Shapiro-Wilk test returned the p-values less than 0.05 suggesting that the data are not normally distributed. Therefore, non-parametric statistical tests are used in analyzing the data. The reliability test for the internal data consistency returned a Cronbach' alpha coefficient of 0.722 .

\subsection{Likes and Dislikes, Choice of Venue and Device}

The students chose the features of online quizzes that they like the most. The top three features that the students like the most are (1) flexible time for taking the quizzes, (2) being able to use the lecture notes during answering the quizzes and, (3) instant grading. The bar chart in Figure 1 shows the students choice of their favorite online quizzes' features. On the other hand, more than $70 \%$ of the students chose 'not being able to see the correct answer immediately' as the feature that they did not like about the online quizzes. Table 1 lists the other features that the students did not like about the online quizzes. $90 \%$ of the students used a laptop computer for taking the online quizzes; only 5\% used desktop computers and smartphones, respectively for taking the online quizzes. $60 \%$ of the students taking the online quizzes at their dormitory while the rest were taking the quizzes at their family home, library, lecture hall, and cafeteria.

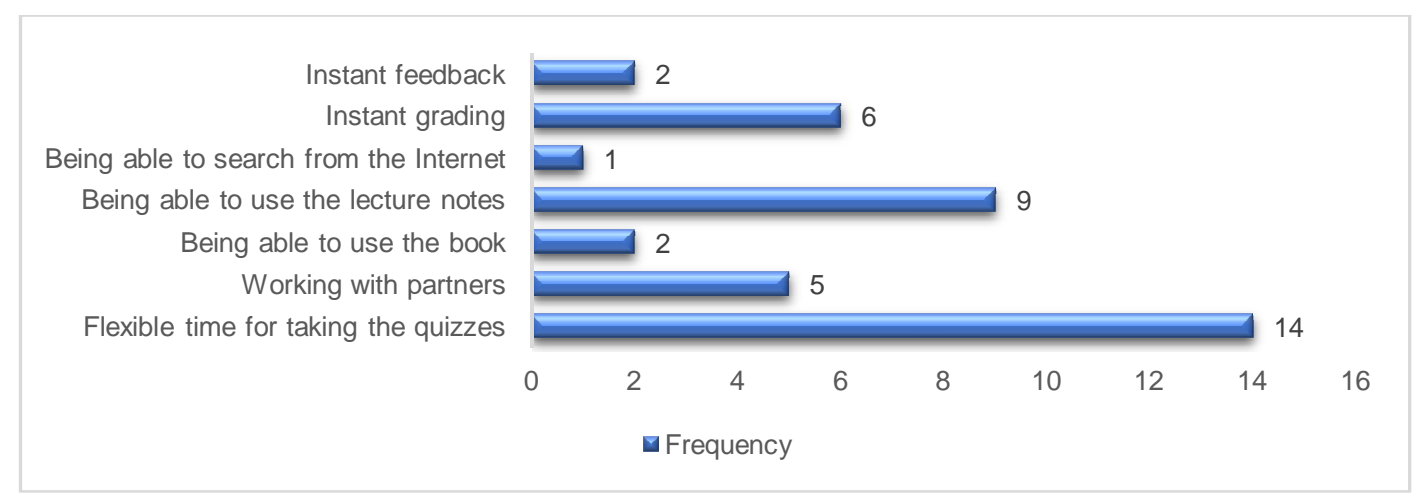

Figure 1: The students' favorite features of online quizzes. 
Table 2: The features of online quizzes that the students did not like

\begin{tabular}{|c|c|}
\hline $\begin{array}{c}\text { What feature of online quizzes that you do } \\
\text { not like? }\end{array}$ & Frequency \\
\hline Having to do it outside of class & 3 \\
\hline $\begin{array}{c}\text { Not being able to see the correct answers right } \\
\text { away }\end{array}$ & 21 \\
\hline Not having easy access to a computer/internet & 11 \\
\hline Other & 4 \\
\hline Total & 39 \\
\hline
\end{tabular}

\subsection{Behaviors and Performance}

The students' behaviors are divided into four types; (1) access to printed references, (2) access to digital references, (3) peer discussion, and (4) test preparation practices. Table 3 shows the means, standard deviations, and median of the students' responses through the post-task questionnaire. Access to printed references and test preparation practices have the highest mean score, respectively, followed by the test preparation practices and peer discussion. In terms of the students' performance, the students have the highest mean score for Quiz 3 that is 4.21, followed by Quiz 2 with 3.82, and Quiz 1 with 3.19, as shown in Table 4. The overall mean mark for the online quizzes is 3.74 .

Table 3: Means, S.D., and median of students' quiz taking behaviors

\begin{tabular}{|c|c|c|c|}
\hline Types of Behavior & Mean & S.D. & Median \\
\hline Access to printed references & 3.54 & 0.935 & 4.00 \\
\hline Access to digital references & 3.45 & 0.705 & 3.50 \\
\hline Peer discussion & 3.15 & 1.136 & 3.00 \\
\hline Test preparation practices & 3.54 & 1.022 & 4.00 \\
\hline
\end{tabular}

Table 4: Means, and S.D. for the quizzes

\begin{tabular}{|c|c|c|c|c|c|c|}
\hline Test Items & $\begin{array}{c}\text { Maximum } \\
\text { Mark }\end{array}$ & $\begin{array}{c}\text { Number } \\
\text { of } \\
\text { questions }\end{array}$ & $\begin{array}{c}\text { Types of } \\
\text { question }\end{array}$ & Topic & Mean & S. D. \\
\hline Quiz 1 & 5 & 15 & $\begin{array}{c}\text { Short } \\
\text { answer } \\
\text { questions }\end{array}$ & $\begin{array}{c}\text { Binary } \\
\text { numbers }\end{array}$ & 3.19 & 1.36 \\
\hline Quiz 2 & 5 & 10 & $\begin{array}{c}\text { Short } \\
\text { answer } \\
\text { questions }\end{array}$ & $\begin{array}{c}\text { Logic } \\
\text { gates }\end{array}$ & 3.82 & 1.05 \\
\hline Quiz 3 & 5 & 10 & $\begin{array}{c}\text { Multiple- } \\
\text { choice } \\
\text { questions }\end{array}$ & CPU & 4.21 & 0.82 \\
\hline \multicolumn{7}{|c|}{ Overall } \\
\hline
\end{tabular}

The study analyzed relationships between the students' performance and their behaviors. Spearman rank-order correlation coefficients for the mean mark and the individual types of behavior were calculated and summarized in Table 5. Positive correlations were reported between individual types of behavior with the mean mark of the online quizzes.

The students' overall performance of the online quizzes was classified into two homogenous groups using k-mean clustering. Twenty-five students scored higher marks in the quizzes were assigned to Cluster 1 . This cluster obtained a minimum score of 3.58 and the maximum score of 4.89 with the cluster centroid of 4.23 . On the other hand, 14 students who scored lower mean mark in the online quizzes were assigned to Cluster 2. The marks range from 2.07 to 3.28 , with the cluster centroid of 2.85 . Table 5 summarized the clustering results. The Mann-Whitney U test confirmed that the marks of the two clusters are significantly different.

Table 5: Clusters derived using K-mean clustering

\begin{tabular}{|c|c|c|c|c|}
\hline Cluster & $\begin{array}{c}\text { Num. of } \\
\text { students }\end{array}$ & $\begin{array}{c}\text { Minimum } \\
\text { marks }\end{array}$ & $\begin{array}{c}\text { Maximum } \\
\text { marks }\end{array}$ & $\begin{array}{c}\text { Cluster } \\
\text { centroid }\end{array}$ \\
\hline 1 & 25 & 3.58 & 4.89 & 4.23 \\
\hline 2 & 14 & 2.07 & 3.28 & 2.85 \\
\hline
\end{tabular}

The two clusters were used for further analysis to see the differences in students' behaviors based on their performance in the online quizzes using a series of MannWhitney $\mathrm{U}$ tests. The test results suggested that students who scored higher marks in the online quizzes rated themselves as having more access to digital references. Further, the students who scored higher marks prepared for earlier for the online quizzes as compared to the students scored lower marks. Table 7 summarizes the statistical values for the analysis. There is no difference between students who scored higher marks and lower marks in terms of their behavior of accessing the printed material and discussing with peers while taking the online quizzes. 
Table 6: Spearman rank-order correlation coefficients

\begin{tabular}{|l|l|l|l|l|}
\hline Spearman's rho & $\begin{array}{l}\text { Access to printed } \\
\text { references }\end{array}$ & $\begin{array}{l}\text { Access to digital } \\
\text { references }\end{array}$ & $\begin{array}{l}\text { Peer } \\
\text { discussion }\end{array}$ & $\begin{array}{l}\text { Test preparation } \\
\text { practices }\end{array}$ \\
\hline $\begin{array}{l}\text { Correlation } \\
\text { Coefficient }\end{array}$ & $0.339^{*}$ & $0.500^{* *}$ & $0.323^{*}$ & $0.464^{* *}$ \\
\hline Sig. (2-tailed) & 0.035 & 0.001 & 0.045 & 0.003 \\
\hline $\mathrm{N}$ & 39 & 39 & 39 & 39 \\
\hline
\end{tabular}

Table 7: Students' quiz taking behaviors between higher and lower marks

\begin{tabular}{|l|c|c|c|c|c|c|c|c|c|}
\hline \multirow{2}{*}{$\begin{array}{l}\text { Types of } \\
\text { Behavior }\end{array}$} & \multicolumn{4}{|c|}{$\begin{array}{c}\text { Students Scored Higher Mark } \\
(\mathbf{n = 2 5})\end{array}$} & \multicolumn{3}{c|}{ Students Scored Lower Mark (n=14) } & \multirow{2}{*}{ Statistics Values } \\
\cline { 2 - 9 } & Mean & S.D. & $\begin{array}{c}\text { Mean } \\
\text { Rank }\end{array}$ & $\begin{array}{c}\text { Sum of } \\
\text { Rank }\end{array}$ & Mean & S.D. & $\begin{array}{c}\text { Mean } \\
\text { Rank }\end{array}$ & $\begin{array}{c}\text { Sum of } \\
\text { Rank }\end{array}$ & \\
\hline $\begin{array}{l}\text { Access to printed } \\
\text { references }\end{array}$ & 3.76 & 0.723 & 22.02 & 550.50 & 3.143 & 1.151 & 16.39 & 229.50 & $\mathrm{U}=124.5, \mathrm{p}=0.127$ \\
\hline $\begin{array}{l}\text { Access to digital } \\
\text { references }\end{array}$ & 3.68 & 0.610 & 23.68 & 592.00 & 3.036 & 0.692 & 13.43 & 188.00 & $\mathrm{U}=83, \mathrm{p}=0.005$ \\
\hline Peer discussion & 3.32 & 1.108 & 21.74 & 543.50 & 2.86 & 1.167 & 16.89 & 236.50 & $\mathrm{U}=131.5, \mathrm{p}=0.184$ \\
\hline $\begin{array}{l}\text { Test preparation } \\
\text { practices }\end{array}$ & 3.92 & 0.954 & 24.34 & 608.50 & 2.86 & 3.036 & 12.25 & 171.50 & $\mathrm{U}=66.5, \mathrm{p}=0.001$ \\
\hline
\end{tabular}

\subsection{Discussions}

This section revisits the hypotheses and the results obtained from the analysis. For $\mathrm{H} 1$ - The students' online quiz taking behavior has a relationship with their performance. This behavior is characterized by access to printed references, access to digital references, peer discussion, and test preparation practices. Students who frequently access to printed references, access to digital references, have peer discussion and prepare or do revision before taking the quizzes obtained higher marks for the online quizzes compared to the students who never or seldom do so. The hypothesis is accepted based on the Spearman Rank Order correlation coefficients presented in Table 5. For H2 Students who scored higher marks have different online quiz taking behavior than the students who scored lower marks. This hypothesis is accepted specifically for accessing digital references and test preparation practices. Students who have higher scores or marks for the online quizzes have different online quiz taking behaviors as compared to the students who obtained lower marks. In simpler words, students who obtained higher marks in the online quizzes tend to refer to digital references (i.e., softcopy of the lecture notes, and search from the Internet) more frequently than the students who obtained lower marks. The hypothesis is accepted based on the Mann-Whitney $U$ test presented in Table 7. The findings of the study could be useful for students who involve in unsupervised online quizzes. Preparation and revision before the quizzes are essential, although there are resources available to refer to while taking the unsupervised online quizzes. The early preparation equipped the students with the knowledge needed for answering the online quiz. As the time given to answer the quizzes is limited; it is crucial to understand the knowledge in depth and know the exact location of the content in the softcopy of the lecture notes or book to confirm the answer. On the other hand, peer discussion while taking the quizzes might not help in increasing the marks for the quizzes.

\section{CONCLUSION}

The findings of this study suggested that the students' online quiz taking behavior has a relationship with their performance, and students who scored higher marks have different online quiz taking behavior than the students who scored lower marks. Although the study has limitations in terms of the small sample size and specific knowledge for Computer Organization, the findings provide empirical evidence of students' online quiz taking behavior and its relationships with their performance. More studies with larger sample sizes are needed and cover more domains of knowledge.

\section{REFERENCES}

1. H. J. Mohammed, M. M. Kasim, and I. N. Mohd. Multicriteria evaluation of e-learning approaches, in International Conference on Computing and Informatics, 2017, pp. 487-491.

2. K. F. Hashim, F. B. Tan, and A. Rashid. Adult learners' intention to adopt mobile learning: A motivational perspective, British Journal of Educational Technology, vol. 46, pp. 381-390, 2015. https://doi.org/10.1111/bjet.12148

3. S. B. Zaibon and E. Yunus. Perceptions of Computational Thinking in Game Based Learning for Improving Student Problem Solving Skills, International Journal of Advanced Trends in Computer Science and Engineering, vol. 8, pp. 181-184, 2019. 
https://doi.org/10.30534/ijatcse/2019/3681.32019

4. M. Omar and A. O. Mohamed. A requirements modeling for e-learning management system (ELMS), International Journal of Innovative Technology and Exploring Engineering, vol. 8, pp. 132-139, 2019.

5. H. Awang, Z. M. Aji, W. R. S. Osman, M. F. M. Yaakob, and $M$. Y. Ibrahim. Content validity testing of instrument to measure Virtual Learning Environment (VLE) success among teachers, International Journal of Civil Engineering and Technology, vol. 9, pp. 1378-1385, 2018.

6. S. Chayanukro, M. Mahmuddin, and H. Husni. A generalized e-learning usage behaviour model by data mining technique, Journal of Information and Communication Technology, vol. 13, pp. 37-53, 2014.

7. A. C. O. Dizon, S. An, A. A. Lubguban, and G. J. Suppes. Online quiz methods for remedial learning in chemical engineering, Education for Chemical Engineers, vol. 23, pp. 18-24, 2018.

https://doi.org/10.1016/j.ece.2018.04.001

8. A. M. Pinto-Llorente, M. C. Sánchez-Gómez, and F. J. García-Peñalvo. The Use of Online Quizzes in Blended Learning Modality: A Qualitative Approach, in Proceedings of the 5th International Conference on Technological Ecosystems for Enhancing Multiculturality, 2017, p. 80. https://doi.org/10.1145/3144826.3145430

9. N. Omar, M. M. Mohamad, and A. N. Paimin. Dimension of learning styles and students' academic achievement, Procedia-Social and Behavioral Sciences, vol. 204, pp. 172-182, 2015.

https://doi.org/10.1016/j.sbspro.2015.08.130

10. S. Bussaman, W. Nuankaew, P. Nuankaew, N. Rachata, K. Phanniphong, and P. Jedeejit. Prediction models of learning strategies and learning achievement for lifelong learning, in 2017 IEEE 6th International Conference on Teaching, Assessment, and Learning for Engineering (TALE), 2017, pp. 192-197. https://doi.org/10.1109/TALE.2017.8252332

11. S. F. Sidek, M. H. M. Yatim, and S. A. Ariffin. The Acceptance Factors and Effectiveness of MOOC in the Blended Learning of Computer Architecture and Organization Course, International Journal of Advanced Trends in Computer Science and Engineering, vol. 8, pp. 160-165, 2019. https://doi.org/10.30534/ijatcse/2019/3281.32019

12.H. Awang, W. R. S. Osman, and Z. M. Aji. A Conceptual Model to Evaluate Virtual Learning Environment among Malaysian Teachers, Journal of Telecommunication, Electronic and Computer Engineering (JTEC), vol. 10, pp. 59-63, 2018.

13. E. F. Monk, K. R. Guidry, K. L. Pusecker, and T. W. Ilvento. Blended learning in computing education: It's here but does it work?, Education and Information Technologies, pp. 1-22, 2019.

14. I. H. Mohd, N. Hussein, A. H. Aluwi, and M. K. Omar. Enhancing students engagement through blended learning satisfaction and lecturer support, in 2016 IEEE 8th International Conference on Engineering Education (ICEED), 2016, pp. 175-180.
15. G. Akçayır and M. Akçayır. The flipped classroom: A review of its advantages and challenges, Computers \& Education, vol. 126, pp. 334-345, 2018. https://doi.org/10.1016/j.compedu.2018.07.021

16. M. S. I. Abdullahi, N. Salleh, A. Nordin, and A. A. Alwan. Cloud-based learning system for improving students' programming skills and self-efficacy, Journal of Information and Communication Technology, vol. 17, pp. 629-651, 2018.

17. E. Redondo, J. Regot, D. Fonseca, F. Valls, and L. Giménez. What is the question?: impact of question length and illustration support on the success and skip rates of preuniversity mock online tests, in Proceedings of the Fourth International Conference on Technological Ecosystems for Enhancing Multiculturality, 2016, pp. 91-97. https://doi.org/10.1145/3012430.3012502

18.S. Sasidhar and S. Sahoo. A Blended Learning Approach to Enhance Student Learning for an Introductory Power Systems Course, in 2018 IEEE Frontiers in Education Conference (FIE), 2018, pp. 1-5.

19. J. Kibble. Use of unsupervised online quizzes as formative assessment in a medical physiology course: effects of incentives on student participation and performance, Advances in Physiology Education, vol. 31, pp. 253-260, 2007. https://doi.org/10.1152/advan.00027.2007

20. S. Paturusi, Y. Chisaki, and T. Usagawa. Development and evaluation of online quizzes to enhance learning performance: A survey of student assessment through MOODLE in Indonesian National University, in Proceedings of International Conference on Information, Communication Technology and System (ICTS) 2014, 2014, pp. 211-216.

21. I. Shimizu, H. Nakazawa, Y. Sato, I. H. Wolfhagen, and K. D. Könings. Does blended problem-based learning make Asian medical students active learners?: a prospective comparative study, BMC medical education, vol. 19, p. 147, 2019. https://doi.org/10.1186/s12909-019-1575-1

22. J. L. Dobson. The use of formative online quizzes to enhance class preparation and scores on summative exams, Advances in Physiology Education, vol. 32, pp. 297-302, 2008.

23. T. Thomas, D. Jacobs, L. Hurley, J. Martin, S. Maslyuk, M. Lyall, et al. Students' perspectives of early assessment tasks in their first-year at university, Assessment \& Evaluation in Higher Education, vol. 44, pp. 398-414, 2019.

24. M. Galizzi. An assessment of the impact of online quizzes and textbook resources on students' learning, International Review of Economics Education, vol. 9, pp. 31-43, 2010. https://doi.org/10.1016/S1477-3880(15)30062-1

25. R. Wang, H. Ryu, and N. Katuk. Assessment of students' cognitive-affective states in learning within a computer-based environment: effects on performance, Journal of Information and Communication Technology, vol. 14, pp. 153-176, 2015. 
26. H.-J. Steenhuis, B. Grinder, and E. J. De Bruijn. The use (lessness) of online quizzes for achieving student learning, International Journal of Information and Operations Management Education, vol. 3, pp. 119-148, 2009.

27. N. Katuk. Progressive assessment of student engagement with web $\square$ based guided learning, Interactive Technology and Smart Education, vol. 10, pp. 116-129, 2013.

28. N. Nasirun, S. M. Noor, R. Z. Yusoff, and A. A. Othman. Student Engagement, Student Interactions and Student Satisfaction in Blended Leaning: A Case of Entrepreneurship Education, Advanced Science Letters, vol. 23, pp. 7952-7955, 2017. https://doi.org/10.1166/asl.2017.9617

29. G. Watson and J. Sottile. Cheating in the Digital Age: Do students cheat more in on-line courses?, in Society for Information Technology \& Teacher Education International Conference, 2008, pp. 798-803.

30.R. K. Ladyshewsky. Post-graduate student performance in 'supervised in-class' vs. 'unsupervised online'multiple choice tests: implications for cheating and test security, Assessment \& Evaluation in Higher Education, vol. 40, pp. 883-897, 2015. https://doi.org/10.1080/02602938.2014.956683

31. K. K. Hollister and M. L. Berenson. Proctored versus unproctored online exams: Studying the impact of exam environment on student performance, Decision Sciences Journal of Innovative Education, vol. 7, pp. 271-294, 2009. https://doi.org/10.1111/j.1540-4609.2008.00220.x

32. A. Gholami and L. Y. Zhang. Student Behaviour in Unsupervised Online Quizzes: A Closer Look, in Proceedings of the 23rd Western Canadian Conference on Computing Education, 2018, p. 8. https://doi.org/10.1145/3209635.3209650

33. S. Cross, M. Sharples, G. Healing, and J. Ellis. Distance Learners' Use of Handheld Technologies: Mobile Learning Activity, Changing Study Habits, and the 'Place'of Anywhere Learning, International Review of Research in Open and Distributed Learning, vol. 20, 2019.

https://doi.org/10.19173/irrodl.v20i2.4040 